\title{
Textures and compositions of cobalt pentlandite and cobaltian mackinawite from the Madan-Kudan copper deposit, Khetri Copper Belt, Rajasthan, India
}

\author{
Abu Saeed Baidya, Atlanta Sen and Dipak C Pal* \\ Department of Geological Sciences, Jadavpur University, Kolkata 700 032, India. \\ *Corresponding author.e-mail:dcpaly2k@yahoo.com;dcpal@geology.jdvu.ac.in
}

MS received 6 June 2017; revised 6 September 2017; accepted 15 September 2017; published online 23 May 2018

The Khetri Copper Belt (KCB), a part of the Proterozoic Delhi-Aravalli fold belt in western India, hosts several $\mathrm{Cu}$ deposits, which are known to contain considerable $\mathrm{Au}, \mathrm{Ag}$, Co and Ni. Although many Cobearing phases have been reported from the KCB and adjacent areas, detailed textural and geochemical data are either unavailable or scant except for mackinawite. In this study, we describe the textures and compositions (determined by EPMA) of two very rare Co-rich phases, namely cobaltian mackinawite (containing up to 12.68 wt.\% Co, $1.90 \mathrm{wt} . \% \mathrm{Ni}$ and $2.52 \mathrm{wt} . \% \mathrm{Cu}$ ) and cobalt-pentlandite (containing up to 49.30 wt.\% Co and 10.19 wt.\% Ni), identified based on composition, from the Madan-Kudan deposit. To the best of our knowledge, neither cobalt-pentlandite nor such highly Co-rich mackinawite have previously been reported from this area. The common sulphide minerals viz. chalcopyrite, pyrrhotite and rare pyrite occur in chalcopyrite-pyrrhotite \pm pyrite-magnetite-chlorite-blue amphibole (Cl-rich hastingsitepargasite-sadanagaite) \pm marialitic scapolite \pm allanite \pm uraninite veins in amphibole-bearing feldspathic quartzite and garnetiferous chlorite schist. Cobaltian mackinawite is invariably associated with chalcopyrite and occurs as exsolution and inclusion within chalcopyrite or outside, but at the contact of chalcopyrite. On the other hand, cobalt-pentlandite is invariably associated with pyrrhotite and shows similar textural relation with pyrrhotite as that of mackinawite with chalcopyrite. Mineralogically diverse undeformed sulphide veins comprising Cl-rich amphibole and locally Cl-rich marialitic scapolite suggests epigenetic hydrothermal mineralization involving Cl-rich saline fluid in the Madan-Kudan deposit. Transport of metals, derived from a mafic source rock with high intrinsic Ni:Co ratio, by Cl-rich fluid can suitably explain the high Co:Ni ratio of the studied ore minerals. Presence of such highly Co-rich phases and other circumstantial evidences, enumerated in this work, are consistent with variants of Fe oxide $(-\mathrm{Cu}-\mathrm{Au})(\mathrm{IOCG})$ style mineralization, at least for some stages of mineralization in the Madan-Kudan deposit.

Keywords. Cobalt pentlandite; cobaltian mackinawite; Madan-Kudan; Khetri; Rajasthan; hydrothermal; copper deposit; India.

\section{Introduction}

The Proterozoic Delhi-Aravalli fold belt in western India hosts several base metal sulphide deposits
(Sarkar and Gupta 2012 and references therein). Unlike $\mathrm{Pb}-\mathrm{Zn}$ mineralization in many other deposits in the fold belt, the Khetri Copper Belt (KCB), situated in the northwestern part, is known 
primarily for its copper mineralization. Besides $\mathrm{Cu}$, the ore deposits in this belt are known to contain elevated concentrations of $\mathrm{Au}, \mathrm{U}, \mathrm{REE}, \mathrm{Fe}$, Ag, and Co (Knight et al. 2002; Sarkar and Gupta 2012). Previous workers have reported chalcopyrite, pyrrhotite, and pyrite as the main sulphide minerals along with minor cubanite, marcasite, molybdenite, sphalerite, pentlandite and mackinawite (Deb and Mukherjee 1969; Sarkar and Dasgupta 1980a, b; Mukherjee and Sen 1991; Sarkar and Gupta 2012) from the KCB. In addition to $\mathrm{Ni}-\mathrm{Co}-$ bearing mackinawite and cobaltite, two very rare Co-rich phases namely danaite (Co-rich variety of arsenopyrite; Mallet 1881) and jaipurite (CoS; Middleton 1846; Nicol 1849) have also been reported from this region. However, there has been no further report of these minerals since their first reports (op cit). On the other hand, textural studies have been done on $\mathrm{Co}-\mathrm{Ni}$-bearing mackinawite from the Madan-Kudan, Kolihan and Chandmari deposits (Rao and Rao 1968; Deb and Mukherjee 1969; Mukherjee and Sen 1991). While quantitative chemical composition of $\mathrm{Co}-\mathrm{Ni}$-bearing mackinawite is available from the Kolihan-Chandmari deposits, such data from the Madan-Kudan deposit is limited and semi-quantitative (Deb and Mukherjee 1969). In this contribution, we describe the textures and compositions of two very rare Corich phases, namely Co-pentlandite and cobaltian mackinawite from the Madan-Kudan copper deposit and discuss their possible implications in mineralization.

\section{Geological background}

The KCB is the northern extension of the Proterozoic Aravalli-Delhi Fold Belt. The Mesoarchean Banded Gneissic Complex (BGC: 3.3-3.0 Ga; Heron 1953; Gopalan et al. 1990; Roy and Kröner 1996; Wiedenbeck et al. 1996) with enclaves of isofacially metamorphosed mafic igneous and sedimentary rocks (Roy 1988; Roy and Jakhar $2002)$ and several Neoarchaean $(\sim 2.8$ to $\sim 2.5 \mathrm{Ga}$; Choudhary et al. 1984; Tobisch et al. 1994; Wiedenbeck et al. 1996) granitoid intrusions form the basement for the younger Proterozoic volcanosedimentary sequences of this fold belt (figure 1). The part of the Aravalli-Delhi fold belt that comprises Delhi Supergroup rocks is divided into two sub-belts namely the North Delhi Fold Belt (NDFB) and the South Delhi Fold Belt (SDFB; Sinha-Roy 1984). The KCB (figure 1b) is on the northwestern part of the NDFB and comprises metamorphosed arenaceous, argillaceous, and calcareous sedimentary rocks associated with mafic volcanic rocks belonging to Alwar and Ajabgarh Group (Heron 1953; Das Gupta 1968; Sarkar and Dasgupta 1980a, b; Roy and Jakhar 2002) of the Delhi Supergroup.

The KCB (figure 1b) extends for about $80 \mathrm{~km}$ from Singhana (Jhunjhunu district) in the NE to Sangarve (Sikar district) in the SW. The copper belt is divided, physically and geographically, into the North Khetri Copper Belt (NKCB) and the South Khetri Copper Belt (SKCB) by the Kanti Fault (figure 1b; Gupta et al. 1998). The Madan-Kudan deposit is located in the NKCB. The basement of the meta-sedimentary units in the NKCB is represented by the $\sim 1.82 \mathrm{Ga}$ calc alkaline granitic rocks and $1.70 \mathrm{Ga}$ albitized Atype granites (e.g., Gothara Granite, figure 2a; Kaur et al. 2007, 2009, 2011). The different rock types, exposed in and around the deposits of the NKCB, include mica schist/phyllite, quartzite, garnetiferous chlorite schist, banded amphibolebearing quartzite and feldspathic quartzite (Sarkar and Gupta 2012). The rocks of NKCB are multiply deformed and poly-metamorphosed (e.g., Das Gupta 1968; Naha et al. 1988; Gupta et al. 1998). Two phases of regional metamorphism, namely $\mathrm{M}_{1}$ and $\mathrm{M}_{2}$ (Lal and Shukla 1975; Lal and Ackermand 1981; Gupta et al. 1998) are inferred to have taken place at $550 \pm 50^{\circ} \mathrm{C}$ and $550-650^{\circ} \mathrm{C}$, respectively with pressure ranging from 300 to $500 \mathrm{MPa}$ (e.g., Lal and Shukla 1975; Sarkar and Dasgupta 1980a, b; Lal and Ackermand 1981; Gupta et al. 1998). The last major metamorphic event has been dated at 950-910 Ma through chemical dating of monazite (Kaur et al. 2006; Pant et al. 2008). Previous workers have reported widespread post-metamorphic hydrothermal alterations (Roy Chowdhury and Das Gupta 1965; Kaur et al. 2012; Knight et al. 2002). Roy Chowdhury and Das Gupta (1965) reported Fe-Mg metasomatism, chloritization, biotitization, sericitization and silicification. Knight et al. (2002) demonstrated that the NKCB rocks have been overprinted by regionally pervasive calc-silicate and sodic alteration. More recent studies also demonstrate multiple stages of regional sodic alteration (Kaur et al. 2012, 2014).

\section{Methodology}

The samples, collected from the Madan-Kudan underground $\mathrm{Cu}$ mine are first studied in hand 


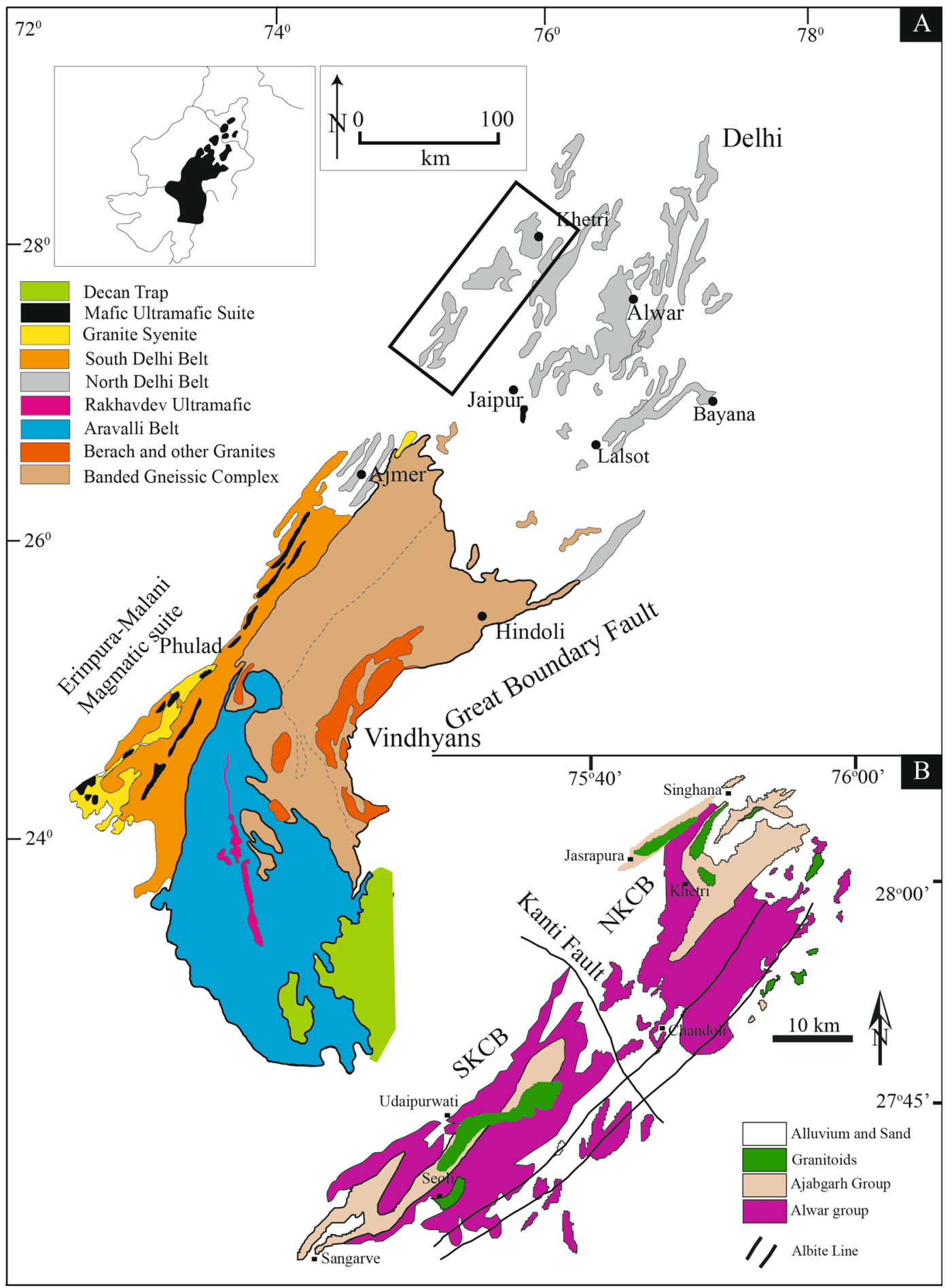

Figure 1. Location of Khetri Copper Belt (KCB) in regional geological set-up of Aravalli-Delhi Fold Belt. Map-A shows the position of KCB in Aravalli-Delhi fold belt (redrawn from Roy 1988 and Roy and Jakhar 2002) and Map-B (redrawn from Kaur et al. 2009) shows the location of North and South Khetri Copper belt. The study area is a part of NKCB.

specimen and with optical microscope. The ore minerals were analyzed by Electron Probe Micro Analyzer (EPMA), at the Department of Geology and Geophysics, IIT Kharagpur. EPMA analysis was conducted on a CAMECA SX-100 machine equipped with four wavelength-dispersive spectrometers (WDS). In the minerals, described here, elements other than $\mathrm{Fe}, \mathrm{S}, \mathrm{Co}, \mathrm{Ni}$, and $\mathrm{Cu}$ are all below detection limit. Therefore details of the analytical conditions for other elements are not given here. For all analyses, a $20 \mathrm{kV}$ accelerating potential and $15 \mathrm{nA}$ current is used. 


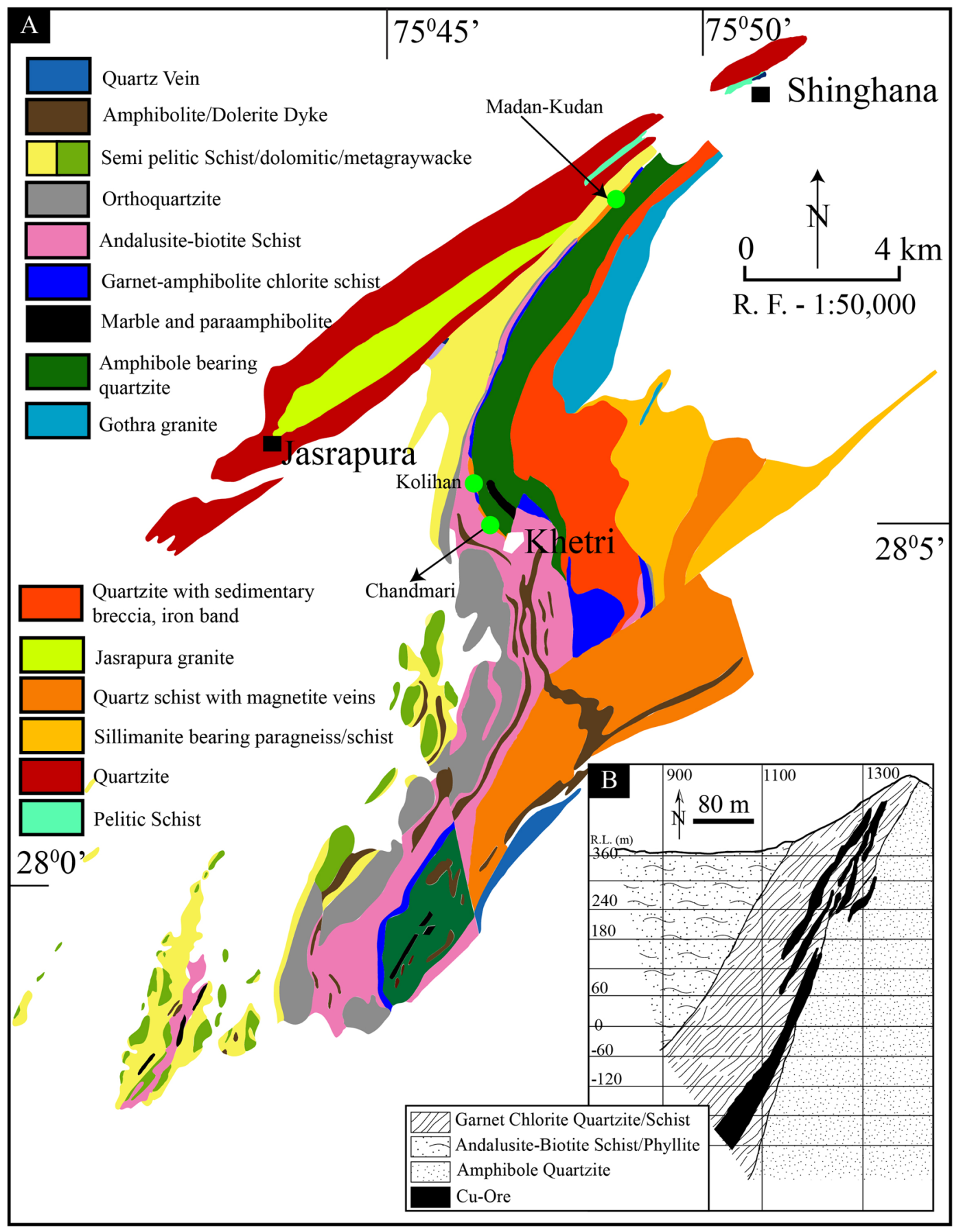

Figure 2. (a) Location of Madan-Kudan and other copper deposits in NKCB (redrawn from Geological Survey of India 1997). The map also shows the major rock types in and around the study area. (b) The cross section of Madan-Kudan deposit (redrawn from Sarkar and Gupta 2012) showing the lithounits and ore bodies. Note that ore bodies are not restricted to a single litho-unit.

Iron and sulphur were analyzed for $10 \mathrm{~s}$ and Co, $\mathrm{Ni}, \mathrm{Cu}$ for $20 \mathrm{~s}$. The background measurement time for $\mathrm{Fe}$ and $\mathrm{S}$ were $5 \mathrm{~s}$ and for $\mathrm{Co}, \mathrm{Ni}$ and $\mathrm{Cu}$ were $10 \mathrm{~s}$. The following standards were used for the analysis, pyrite $(\mathrm{FeK} \alpha, \mathrm{SK} \alpha)$, and pure metals of $\mathrm{Co}(\mathrm{CoK} \alpha), \mathrm{Ni}(\mathrm{NiK} \alpha)$, and $\mathrm{Cu}$ $(\mathrm{CuK} \alpha)$.

\section{Results}

4.1 Host rocks and mode of occurrences of sulphides

Sulphide mineralization in the Madan-Kudan copper mine is hosted by quartzite/amphibole-bearing 

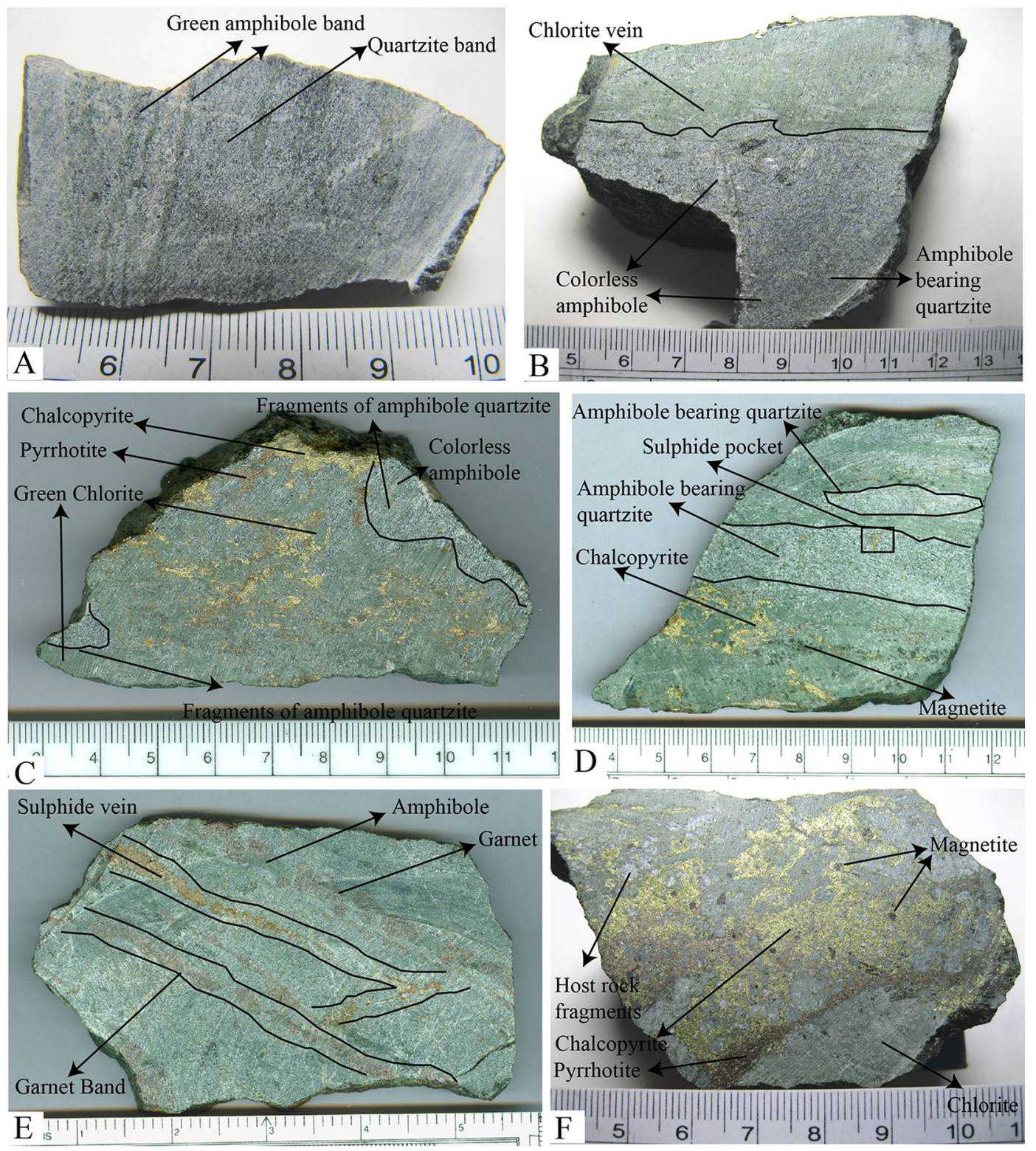

Figure 3. Rock types from Madan-Kudan deposit. Note that all the rock types have been dissected by mineralogically different vein, e.g., (a) green amphibole vein, (b) chlorite vein, (c, $\mathbf{d}$ and $\mathbf{f}$ ) sulphide-magnetite-chlorite-blue amphibole vein and (e) massive sulphide vein. Note the presence of colourless amphibole-bearing quartzite/quartzite fragments in the veins.

massive or banded quartzite (figures 1a, 3a and b) and garnetiferous chlorite schist (figure 3e). The quartzite in the study area is commonly feldspathic in nature comprising predominantly of quartz and albite. Amphibole-bearing quartzite consists of quartz, albite and amphibole along with minor chlorite and biotite. Optically colourless amphibole, namely cummingtonite-grunerite, is present as randomly oriented grains (figure $3 b$ ) in the quartz-albitic matrix in amphibole-bearing massive quartzite. On the other hand, the banded variety consists of alternate green-coloured magnesioferri-hornblende-rich and quartz-rich bands (figure 3a). Green amphiboles are randomly oriented in amphibole rich bands. Colourless amphiboles are replaced by chlorite and blue-coloured amphibole, the latter compositionally belonging to hastingsitepargasite-sadanagaite (figure $4 \mathrm{a}$ ). In places, the colourless amphibole relicts have been found in chlorite-bearing veins. Similar replacement relation among colourless amphibole and blue amphibole is observed in the Kolihan and Chandmari deposit in the KCB (Baidya et al. 2017). Baidya et al. (2017) have also found that green amphibole (magnesioferri-hornblende), similar to Madan-Kudan deposit has been replaced by blue amphiboles (hastingsitepargasite-sadanagaite). The garnetiferous chlorite schist is composed predominantly of quartz, 

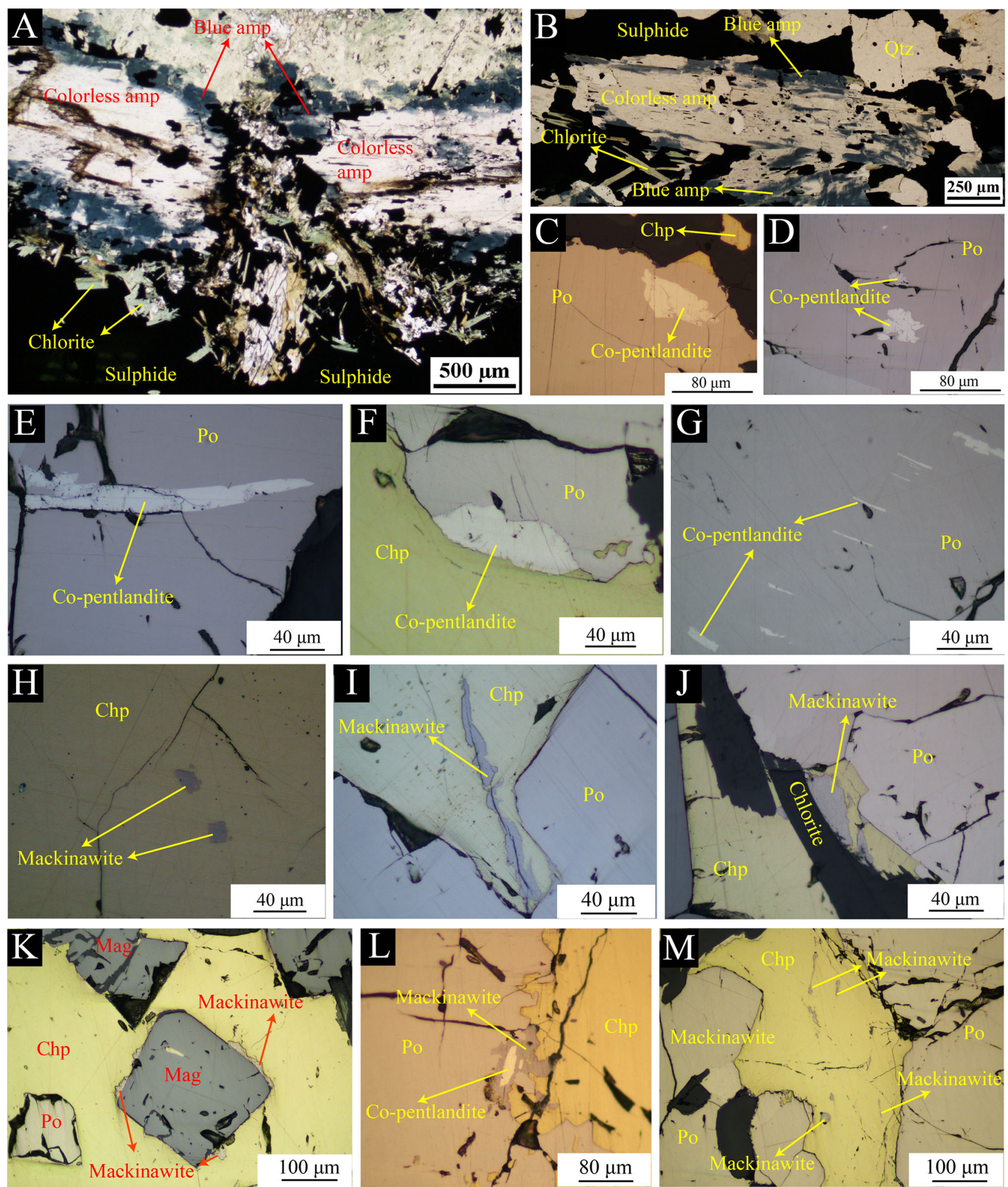

Figure 4. Microscopic images showing the relation between colourless amphibole and blue amphibole-chlorite and sulphide $(\mathbf{a}, \mathbf{b})$ and textures of Co-pentlandite and cobaltian mackinawite. Cobalt-pentlandite is present as inclusions of different shape in pyrrhotite (c, $\mathbf{d}$ and $\mathbf{e}$ ), along the contact zone of pyrrhotite and other minerals $(\mathbf{f})$ and as exsolved tabular/elongated oriented lamella in pyrrhotite (g). Cobaltian mackinawite is present as inclusion in chalcopyrite (h), as thin elongated vein (i and $\mathbf{m}$ ), at contact zone between chalcopyrite and other minerals (j and $\mathbf{k})$. Amp, Chp, Mag and Po in the microphotographs stands for amphibole, chalcopyrite, magnetite and pyrrhotite, respectively. 
feldspar, garnet, amphibole, chlorite and biotite with accessory zircon, ilmenite and magnetite. Garnet occurs either in garnet \pm amphibole bands (figure 3e) or as disseminated porphyroblasts. The schistosity, defined by oriented chlorite and minor amount of biotite, locally warps around garnet porphyroblasts. In addition, chlorite and biotite, probably of new generation, replaces garnet along fractures and grain boundaries.

In amphibole-bearing quartzite and garnetiferous chlorite schist, sulphides occur mainly in the form of veins and stringers and locally as small pockets and patches (figure $3 \mathrm{a}-\mathrm{d}$ ). The veins commonly cut-across the metamorphic fabric of the rock and above-mentioned green amphibole band/layer/pocket. The blue amphibole is ubiquitously associated with sulphide veins/pockets (figure $4 \mathrm{a}$ and $\mathrm{b}$ ), either as distinct grains or as replacement product of existing colourless and probably green amphiboles ( $c f$. Baidya et al. 2017). The host rock is highly fractured and brecciated and in some cases the host rock fragments occur in the sulphide veins (figure $3 \mathrm{c}, \mathrm{f}$ ). The sulphide veins are mineralogically diverse (Sen 2015; Baidya et al. 2017). The Co-rich phases, described in this study are observed in chalcopyrite-pyrrhotite \pm pyritemagnetite-chlorite-blue amphibole (Cl-rich hastingsite-pargasite-sadanagaite) \pm marialitic scapolite \pm allanite \pm uraninite veins (Sen 2015; Baidya et al. 2017). This mineralogical assemblage of the veins is consistently present in the study area, which implies that the formation of the individual sulphide minerals in the veins is not widely separated in time and space. Chalcopyrite and pyrrhotite, the two ubiquitous sulphide minerals in the veins have mutual straight boundary contact. Additionally, inclusions of chalcopyrite occur in pyrrhotite and vice versa. At places, partly corroded grains of pyrrhotite are embedded in chalcopyrite. All these textures collectively indicate a virtually single hydrothermal event of mineralization in which the ore mineral precipitation was largely synchronous. However, in some places chalcopyrite crystallization outlasted that of pyrrhotite and corroded existing pyrrhotite by a somewhat evolved/modified fluid of same parentage.

\subsection{Textures of Co-rich sulphide phases}

The highly Co-rich mineral (up to 50 wt.\% Co; see section on geochemistry), that we assign as cobalt pentlandite based on its composition (see sections 5 and 6.1), is characterized by pinkish/ creamy yellow colour in reflected plane polarized light and higher reflectance relative to both chalcopyrite and pyrrhotite. Polishing hardness is somewhat higher than chalcopyrite, but distinctly lower than pyrrhotite. Its scratching hardness is higher than that of chalcopyrite, but lower than that of pyrrhotite (see grain boundaries in figures $4 \mathrm{f}$ ). The mineral is also anisotropic, unlike most common pentlandite sensu stricto. This mineral is invariably intimately associated with pyrrhotite. It is present as isolated euhedral to subhedral inclusions within pyrrhotite (figure $4 \mathrm{c}-$ e) as oriented flames within pyrrhotite (figure $4 \mathrm{~g}$ ) at the contact (but commonly inside pyrrhotite) of pyrrhotite with other minerals, viz., -chlorite, magnetite and chalcopyrite (figure 4f). The inclusions are of different shapes and sizes. Shape varies from elongated/tabular to almost equidimensional (compare figure $4 \mathrm{c}-\mathrm{e}$ ). The oriented flames are euhedral in shape and smaller in size relative to other grains with different mode of occurrences (figure $4 \mathrm{~g}$ ). This phase is fractured in places and seemed to have been replaced by another unidentified phase (figure 4e).

Mackinawite is pleochroic and anisotropic. In plane polarized reflected light the grains change its colour from grayish pink to pinkish gray. It has higher hardness relative to chalcopyrite and similar to that of pyrrhotite. Mackinawite is exclusively associated with chalcopyrite and present in different forms. It is present as thin lamella and streaks, long elongated (figure $4 \mathrm{~m}$ ) or small anhedral inclusions in chalcopyrite (figure 4h), and along microcracks in chalcopyrite (figure 4i). It also occurs outside, but at the contact of chalcopyrite with other minerals, viz., chlorite (figure $4 \mathrm{j}$ ), quartz, magnetite (figure 4k) and pyrrhotite (figure 4l). At some places, it occurs onto some silicate veins or inclusions (chlorite and magnetite) in chalcopyrite as if the silicate phase acted as a growth surface for mackinawite (figure $4 \mathrm{j}$ and $\mathrm{k}$ ). Irregular mackinawite, invading into chalcopyrite and pyrite from their contact, contains cobalt-pentlandite inclusions (figure 4l).

\section{Compositions of Co-rich phases}

The compositions of the highly Co-rich phase and mackinawite, obtained from EPMA, are given in tables 1 and 2, respectively. Both the minerals 
Table 1. Chemical composition and calculated formula of Co-pentlandite.

\begin{tabular}{|c|c|c|c|c|c|c|c|c|c|c|}
\hline \multirow{2}{*}{$\begin{array}{l}\text { Sample } \\
\text { no. }\end{array}$} & \multicolumn{5}{|c|}{ Chemical composition } & \multicolumn{5}{|c|}{ Formula based on 17 atoms } \\
\hline & $\mathrm{S}$ & $\mathrm{Fe}$ & Co & $\mathrm{Ni}$ & Total & $\mathrm{S}$ & $\mathrm{Fe}$ & Co & $\mathrm{Ni}$ & $\sum$ metal \\
\hline S4-G-old_1 & 32.53 & 8.98 & 48.93 & 9.41 & 100.67 & 7.961 & 1.262 & 6.516 & 1.258 & 9.04 \\
\hline S4-G-old_2 & 31.82 & 8.71 & 49.30 & 9.06 & 99.54 & 7.885 & 1.239 & 6.647 & 1.227 & 9.11 \\
\hline S4-G-old_3 & 32.07 & 8.86 & 49.09 & 9.41 & 100.14 & 7.893 & 1.252 & 6.574 & 1.265 & 9.09 \\
\hline S4-G-old_4 & 32.62 & 9.39 & 48.17 & 9.38 & 99.88 & 7.997 & 1.322 & 6.425 & 1.256 & 9.00 \\
\hline S4-G-old_5 & 32.81 & 11.60 & 45.38 & 9.65 & 99.92 & 8.033 & 1.631 & 6.045 & 1.291 & 8.97 \\
\hline S4-G-old_6 & 32.24 & 9.15 & 48.94 & 9.34 & 100.12 & 7.916 & 1.290 & 6.538 & 1.253 & 9.08 \\
\hline S4-G-old_7 & .19 & 8.46 & 48.83 & 9.07 & 99.21 & 7.9 & 1.2 & 6.587 & 1.228 & 9.02 \\
\hline S4-G-old_8 & 32.49 & 8.40 & 47.48 & 9.96 & 98.66 & 8.052 & 1.195 & 6.403 & 1.349 & 8.95 \\
\hline S4-G-old_9 & 32.51 & 8.89 & 49.24 & 8.95 & 100.25 & 7.969 & 1.251 & 6.568 & 1.199 & 9.02 \\
\hline S4-G-old_10 & 32.04 & 9.60 & 48.03 & 9.44 & 99.76 & 7.912 & 1.361 & 6.453 & 1.274 & 9.09 \\
\hline S4-G-old_11 & 32.39 & 9.63 & 47.85 & 9.30 & 99.80 & 7.968 & 1.3 & 6.4 & 1.250 & 9.02 \\
\hline S4-G-New_1 & 32.45 & 9.00 & 48.10 & 9.34 & 99.32 & 8.004 & 1.275 & 6.455 & 1.259 & 8.99 \\
\hline S4-G-New_2 & 32.18 & 8.63 & 47.56 & 9.34 & 98.08 & 8.031 & 1.237 & 6.458 & 1.274 & 8.97 \\
\hline S4-G-New_4 & 32.92 & 7.75 & 48.73 & 9.09 & 99.00 & 8.123 & 1.098 & 6.543 & 1.225 & 8.87 \\
\hline S4-G-New_6 & 32.67 & 9.56 & 47.16 & 10.01 & 100.11 & 8.016 & 1.347 & 6.296 & 1.342 & 8.99 \\
\hline S4-G-New_7 & 32.64 & 9.21 & 47.36 & 10.19 & 100.17 & 8.011 & 1.298 & 6.325 & 1.366 & 8.99 \\
\hline S4-G-New_8 & 32.71 & 9.29 & 47.45 & 9.81 & 100.00 & 8.031 & 1.310 & 6.339 & 1.316 & 8.97 \\
\hline S4-G-New_9 & 32.20 & 8.47 & 49.18 & 8.55 & 98.95 & 7.992 & 1.207 & 6.642 & 1.159 & 9.01 \\
\hline S4-G-New_10 & 32.46 & 8.59 & 48.87 & 9.47 & 99.81 & 7.979 & 1.212 & 6.536 & 1.272 & 9.02 \\
\hline
\end{tabular}

Table 2. Chemical composition and calculated formula of cobaltian mackinawite.

\begin{tabular}{|c|c|c|c|c|c|c|c|c|c|c|c|c|}
\hline \multirow{2}{*}{$\begin{array}{l}\text { Sample } \\
\text { no. }\end{array}$} & \multicolumn{6}{|c|}{ Chemical composition } & \multicolumn{6}{|c|}{ Formula based on $\mathrm{S}=1$} \\
\hline & $\mathrm{S}$ & $\mathrm{Fe}$ & $\mathrm{Co}$ & $\mathrm{Ni}$ & $\mathrm{Cu}$ & Total & $\mathrm{S}$ & $\mathrm{Fe}$ & $\mathrm{Co}$ & $\mathrm{Ni}$ & $\mathrm{Cu}$ & $\sum$ metal \\
\hline S4-G_1 & 35.57 & 51.73 & 8.63 & 1.90 & 0.23 & 98.37 & 1.000 & 0.835 & 0.132 & 0.029 & 0.003 & 0.999 \\
\hline S4-G_2 & 35.21 & 49.15 & 12.49 & 0.91 & 0.58 & 98.34 & 1.000 & 0.802 & 0.193 & 0.014 & 0.008 & 1.017 \\
\hline S4-G_3 & 35.78 & 51.64 & 10.60 & 1.11 & 0.11 & 99.30 & 1.000 & 0.829 & 0.161 & 0.017 & 0.001 & 1.008 \\
\hline S4-G_4 & 34.79 & 46.93 & 8.52 & 1.36 & 6.63 & 98.24 & 1.000 & 0.775 & 0.133 & 0.021 & 0.096 & 1.025 \\
\hline S4-G_5 & 35.63 & 50.44 & 10.96 & 1.04 & 0.80 & 99.30 & 1.000 & 0.813 & 0.167 & 0.016 & 0.011 & 1.008 \\
\hline S4-G_6 & 35.38 & 49.93 & 10.89 & 1.07 & 1.11 & 99.17 & 1.000 & 0.810 & 0.167 & 0.017 & 0.016 & 1.010 \\
\hline S4-G-N_1 & 35.60 & 48.64 & 9.78 & 1.33 & 2.02 & 98.01 & 1.000 & 0.785 & 0.149 & 0.020 & 0.029 & 0.983 \\
\hline S4-G-N_2 & 35.88 & 49.04 & 10.35 & 1.03 & 2.52 & 99.40 & 1.000 & 0.785 & 0.157 & 0.016 & 0.035 & 0.993 \\
\hline S4-G-N_3 & 34.96 & 50.21 & 11.39 & 1.22 & 0.38 & 98.81 & 1.000 & 0.825 & 0.177 & 0.019 & 0.005 & 1.026 \\
\hline S4-G-N_4 & 35.87 & 49.14 & 12.68 & 0.77 & 0.21 & 99.72 & 1.000 & 0.787 & 0.192 & 0.012 & 0.003 & 0.994 \\
\hline S4-G-N_5 & 35.67 & 47.58 & 9.37 & 1.63 & 2.43 & 97.24 & 1.000 & 0.766 & 0.143 & 0.025 & 0.034 & 0.968 \\
\hline S4-G-N_6 & 33.80 & 41.76 & 5.56 & 1.07 & 12.64 & 95.24 & 1.000 & 0.709 & 0.090 & 0.017 & 0.189 & 1.005 \\
\hline S4-G-N_7 & 35.24 & 49.96 & 11.15 & 0.96 & 0.36 & 98.09 & 1.000 & 0.814 & 0.172 & 0.015 & 0.005 & 1.006 \\
\hline S4-G-N_8 & 35.76 & 49.73 & 11.20 & 1.00 & 0.43 & 98.94 & 1.000 & 0.799 & 0.170 & 0.015 & 0.006 & 0.990 \\
\hline S4-G-N_9 & 35.08 & 50.55 & 11.50 & 0.95 & 0.43 & 99.23 & 1.000 & 0.827 & 0.178 & 0.015 & 0.006 & 1.027 \\
\hline S4-G-N_10 & 35.44 & 49.91 & 11.42 & 0.94 & 0.56 & 98.82 & 1.000 & 0.809 & 0.175 & 0.014 & 0.008 & 1.006 \\
\hline
\end{tabular}

yield an analytical total of $\sim 100 \mathrm{wt} . \%$. We have not observed any difference in the compositions of different textural types of the minerals. Cobalt pentlandite contains $\mathrm{Fe}$ in the range of 7.75 to $9.63 \mathrm{wt} . \%$, Co in the range of $45.38-49.30 \mathrm{wt} . \%$ and $\mathrm{Ni}$ in the range of $8.55-10.19$ wt.\%. Copper, $\mathrm{Zn}$ and $\mathrm{As}$ are below detection limits. The mineral is sulphur deficient compared to total metal. The formula calculation is done based on 17 atoms ( $c f$. Boradev et al. 2007) and the calculated general formula is (Co, Ni, Fe) ${ }_{9.11-8.86} \mathrm{~S}_{7.88-8.05}$. The metal:sulphur ratios in calculated mineral formula are mostly $\sim 9: 8$ with $<2 \%$ deviation in each site $\left(\mathrm{Me}_{9 \pm 0.18} \mathrm{~S}_{8 \pm 0.16}\right)$ implying a stoichiometric composition with respect to $\mathrm{Me}_{9} \mathrm{~S}_{8}$, typical of pentlandite group minerals. Binary plots have been generated from the atoms per formula unit (apfu) of different metals. Cobalt shows negative correlation with $\mathrm{Fe}$ and $\mathrm{Ni}$ (figure $5 \mathrm{a}$ and $\mathrm{b}$ ). Cobalt also shows strong negative correlation with $\mathrm{Fe}+\mathrm{Ni}$. 

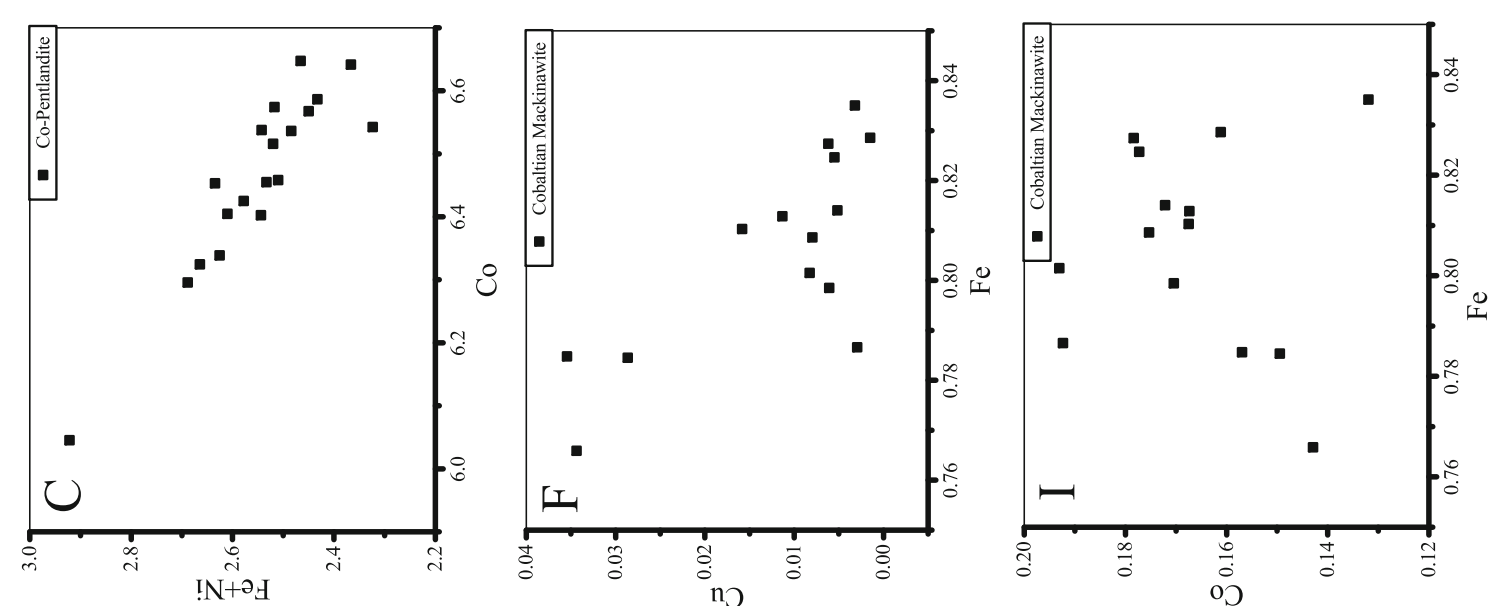

里诖

素.

.

荧

要

苞
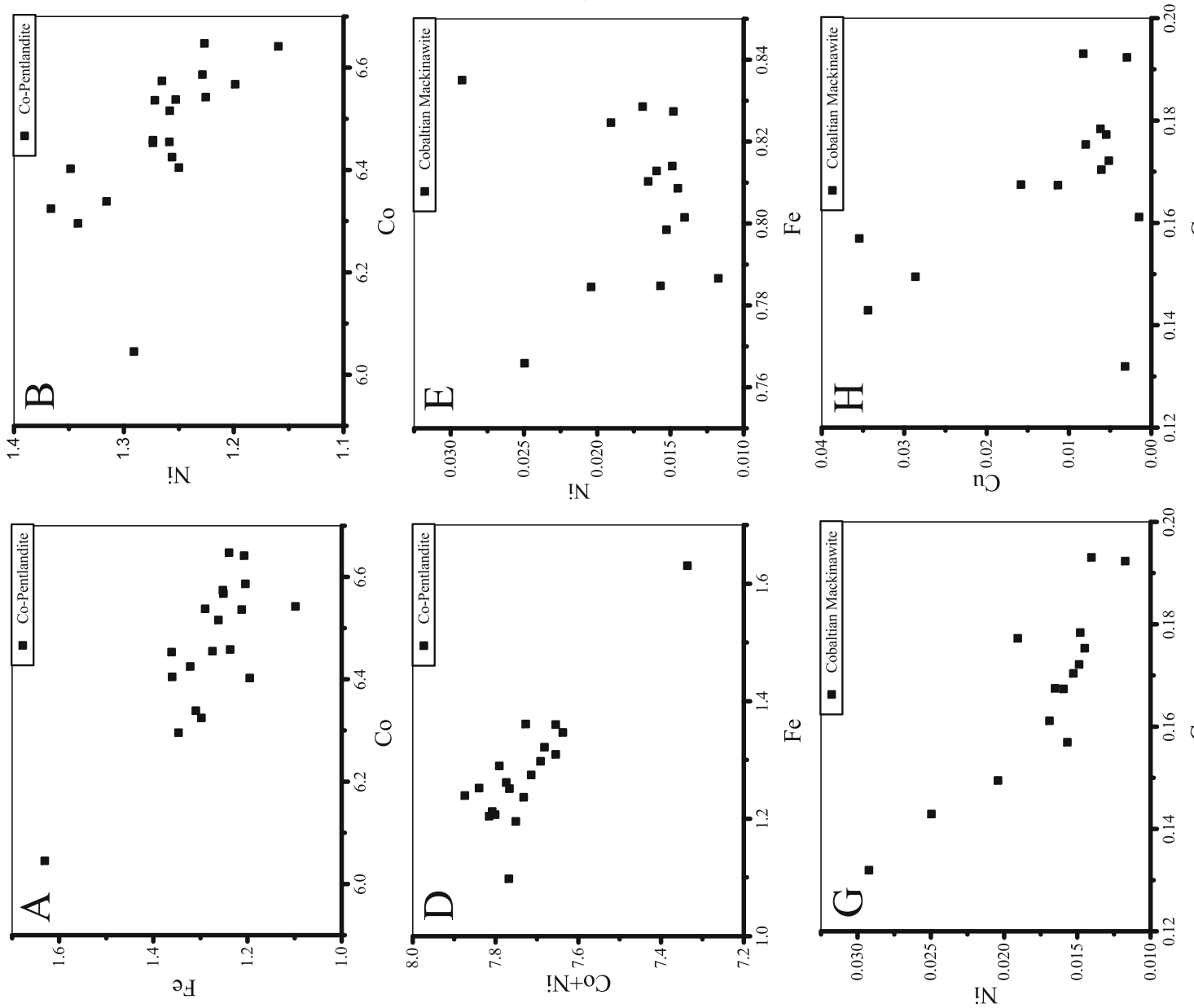

i

$\exists$

of

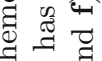

ए 0 ส

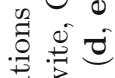

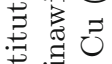

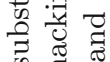

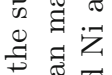

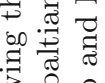

过 0

证表

늘 중

그응

㖊

मा ซ

○江

近 
Similarly Fe also shows strong negative correlation with $\mathrm{Co}+\mathrm{Ni}$. Pyrrhotite that hosts or is associated with this mineral at places contains high Co and Ni (4300-4800 ppm Co and 1100-1500 ppm Ni).

Mackinawite contains high concentrations of Co, $\mathrm{Ni}$ and $\mathrm{Cu}$. Iron content varies from 41.76 to 51.73 wt. $\%$, whereas $\mathrm{Co}$ and $\mathrm{Ni}$ contents vary from 5.56 to $12.68 \mathrm{wt} . \%$, and 0.77 to $1.90 \mathrm{wt} . \%$, respectively. Copper is detected in all grains and $\mathrm{Cu}$ content ranges mostly between 0.21 and 2.52 wt.\% in large grains. Very high $\mathrm{Cu}$ content, up to 12.68 wt. \%, measured in fine-grained inclusions in chalcopyrite may be due to contamination from the surrounding chalcopyrite. Formula calculation is done based on 1 anion. Calculated metal:sulphur ratio is $\sim 1: 1$ in most cases. Neither $\mathrm{Co}$ nor $\mathrm{Ni}$ (apfu) shows any discernible correlation with Fe, whereas $\mathrm{Cu}$ shows a very weak negative correlation with these elements (see figure $5 \mathrm{~d}-\mathrm{f}$ ). Cobalt and $\mathrm{Ni}$ content of host chalcopyrite is below detection limit.

\section{Discussion}

\subsection{Khetri Co-rich phases in the context of global occurrences}

Pentlandite, nominally (Fe, $\mathrm{Ni})_{9} \mathrm{~S}_{8}, \quad$ can accommodate variable amounts of $\mathrm{Co}$ and $\mathrm{Ni}$ in its structure. Harris and Nickel (1972) classified pentlandites based on the Co contents in the structure. Pentlandite proper can have Co as high as 10 wt.\%. Cobalt content for cobaltian pentlandite is $\sim 12-14$ wt. $\%$, whereas cobalt pentlandite contains more than 20 wt.\% Co. Amongst the above Co-bearing pentlandite group minerals, cobalt pentlandite is a very rare Co-bearing sulphide mineral, which was first reported from Finland (Kuovo et al. 1959). Structurally, Co-pentlandite (end member composition is $\left.\mathrm{Co}_{9} \mathrm{~S}_{8}\right)$ is similar to pentlandite, $(\mathrm{Fe}, \mathrm{Ni})_{9} \mathrm{~S}_{8}$, and there is complete solid solubility between them (Geller 1962). The metal:S ratio of the highly Co-rich phase identified in this study is $\sim 9: 8$ resulting in a formula of $\sim(\mathrm{Co}, \mathrm{Ni}$, $\mathrm{Fe})_{9} \mathrm{~S}_{8}$, which suggests that the mineral belongs to the pentlandite group. Based on the classification scheme of Harris and Nickel (1972), and reported compositions of Co-pentlandite from different parts of the world, we identify this mineral as Co-pentlandite. The Co-pentlandite that we report here is somewhat anisotropic. It may be noted that anisotropic, exsolved pentlandite in pyrrhotite has been reported from Sudbury ore and from experimental studies (Francisi et al. 1976). Anomalous anisotropism in cubic pyrite is also not uncommon in literature (e.g., Stanton 1959; Gibbons 1967; Bayliss 1977; Murowchick 1992). We propose that our sample contains such an anomalously anisotropic Co-pentlandite. This is the first reported occurrence of Co-pentlandite from the Khetri region and perhaps from India. To the best of our knowledge, anisotropic Co-pentlandite has hitherto not been reported. It needs to be mentioned here that among the highly Co-rich phases, previously reported from this area, the one that is closest in composition to that of this Copentlandite is a Co-sulphide containing $64.64 \mathrm{wt} . \%$ Co and 35.36 wt.\% S (by chemical analysis), first reported by Middleton (1846). He assigned this mineral to be a sulphuret/sub-sulphuret of cobalt occurring in association with iron pyrites (actually magnetic pyrrhotite based on composition given by Middleton 1846). Although Middleton (1846) proposed the mineral to be $\mathrm{Co}_{2} \mathrm{~S}$, the mineral formula should actually be CoS based on chemical composition. Subsequently, this mineral was named as Syepoorite by Nicol (1849). Ross (1872) reported sulph-antimonial arsenide of cobalt from the Khetri ores, which he named as Jeypoorite. The mineral that Ross (1872) described is reported (op cit) to contain, in oxide percentage, 82 wt. $\%$ Co, 7 wt.\% Sb, 6 wt.\% As, and 5 wt.\% S. Neither Middleton's result has been corroborated by later studies nor the mineral CoS, known as Syepoorite/Jeypoorite/Jaipurite in literature, has further been reported from the Khetri region. To the best of our knowledge, no detailed information is available on the physical, optical and chemical properties of Jaipurite from Khetri or other regions. It is possible that such a mineral exists in Khetri ore. However, we also do not entirely rule out the possibility that the Jaipurite reported from this region may actually be the anomalously pleochroic Co-pentlandite reported in our study.

Mackinawite, nominally $\mathrm{Fe}_{(1+x)} \mathrm{S}$ (where $x$ is between 0 and 0.25 ), can incorporate $\mathrm{Cu}$, Co and Ni (Deb and Mukherjee 1969; Vaughan 1969; Clark 1970; Sarkar 1971; Mukherjee 1976; Mukherjee and Sen 1991; Kwon et al. 2015) in its structure. Previously reported Co-bearing mackinawite from Khetri region is more enriched in $\mathrm{Ni}$, compared to $\mathrm{Co}$ and the total contents of $\mathrm{Co}+\mathrm{Ni}$ range between $\sim 5$ and 11 wt.\% (Deb and Mukherjee 1969; Mukherjee and Sen 1991). In contrast, mackinawite described in this study, is more enriched 
in Co compared to $\mathrm{Ni}$ (table 1) and is closer to cobaltian mackinawite ( $\geq 15 \mathrm{wt} . \% \mathrm{Co}$ ) in composition. Cobaltian mackinawite is rare in nature and described from a very few deposits from other parts of the world (Clark 1970; Tatsumi et al. 1975; Mariko 1988). The Co:Ni ratios (4-16) of the mackinawite, we report here, are quite high relative to other reported $\mathrm{Co}-\mathrm{Ni}$-bearing mackinawite.

\subsection{Sulphide mineralization vis-à-vis Co-pentlandite and cobaltian mackinawite}

In the Madan-Kudan deposit (this study) and nearby Chandmari and Kolihan mine (Baidya et al. 2017) sulphide mineralization is essentially associated with mineralogically diverse sulphide veins in amphibole-bearing quartzite and garnetiferous chlorite schist. Striking differences in the mineralogy of host rocks and that of the veins imply epigenetic hydrothermal sulphide mineralization through ingress of extraneous fluid. These hydrothermal sulphide veins containing Copentlandite and Co-rich mackinawite also contain Cl-rich hastingsite-pargasite-sadanagaite and at places Cl-rich marialitic scapolite (Sen 2015; Baidya et al. 2017). Chlorine-bearing phases strongly indicate that the sulphide mineralization is genetically related to Cl-rich hydrothermal fluid, which may be linked to magmatic or sedimentary basinal brine (Baidya et al. 2017). Some previous works also have proposed hydrothermal origin of the sulphide ores from a Cl-rich hydrothermal fluid in Khetri region (Roy Chowdhury and Das Gupta 1965; Das Gupta 1974; Sahu et al. 1977; Jaireth 1984, 1986; Knight et al. 2002). Randomly oriented grains and un-deformed nature of the veins indicate that the vein-hosted mineralization described in this study was post-deformation and likely post-metamorphic.

The veins containing Co-pentlandite and cobaltian mackinawite also contain magnetite and pyrrhotite as common minerals, while pyrite is either insignificant or absent. Absence of pyrite in the mackinawite-chalcopyrite-pyrrhotite association has previously been observed from Chandmari mine (Mukherjee and Sen 1991). Co-existence of magnetite with pyrrhotite and rarity or absence of pyrite suggests that the fluid from which the veins formed and the ore minerals crystallized, was of low sulphur fugacity. In the light of this discussion, we propose that this event of $\mathrm{Cu}$ mineralization at Madan-Kudan area took place from a Cl-rich low $f \mathrm{~S}_{2}$ fluid.
It may be noted that Co-pentlandite and Co-rich mackinawite exclusively occur in association with pyrrhotite and chalcopyrite, respectively. The oriented flames of Co-pentlandite in pyrrhotite and oriented lamella of cobaltian mackinawite in chalcopyrite might have formed through solid state exsolution during cooling of the host mineral. Exsolved flames of pentlandite in pyrrhotite are common in nature (Ramdohr 1980). Such textures are produced by homogeneous nucleation at several sites by rapid cooling (Craig et al. 1981), whereas the grannular Co-pentlandite occurring near fractures and grain boundaries are produced by diffusion and heterogeneous nucleation during slow cooling from high temperature (op cit). The oriented lamella of mackinawite in chalcopyrite might also have formed in a similar way as the flames of Co-pentlandite in pyrrhotite. Similar explanation has been given for argento-pentlandite and mackinawite inclusions in chalcopyrite in some previous studies (e.g., Merkle and Gruenewaldt 1986; Kerestedjian and Bonev 2001). Merkle and Gruenewaldt (1986) proposed a higher temperature $\left(\sim 300^{\circ} \mathrm{C}\right)$ for inclusion type mackinawite relative to mackinawite of other modes generated at $225 \pm 1{ }^{\circ} \mathrm{C}$ or lower temperature as described by Deb and Mukherjee (1969). Some of the small isolated inclusions of Co-pentlandite and cobaltian mackinawite may be the cross sections of large elongated grains or of exsolved flames and lamella. However, we cannot entirely rule out the possibility of direct crystallization of these Co-rich phases from the hydrothermal fluid, particularly those without any apparent exsolution texture. Whatever be the origin of these Co-rich phases, it is evident that the hydrothermal fluid from which pyrrhotite, chalcopyrite and other minerals crystallized in the veins was extraneous (outside the depositional locale) and brought in Co and $\mathrm{Ni}$ along with $\mathrm{Cu}$ and Fe. During crystallization, $\mathrm{Co}$ and $\mathrm{Ni}$ were incorporated in pyrrhotite and chalcopyrite and during post-crystallization cooling Co-rich phases exsolved in their respective hosts. The distribution, size and shape of the exsolved phases varied depending on temperature and rate of cooling. It is possible that chalcopyrite, which outlasted and partly replaced pyrrhotite might have obtained some Co and Ni from existing pyrrhotite for the formation of some mackinawite at a later stage. Some existing Co-pentlandite also likely replaced by cobaltian mackinawite at this stage. 


\subsection{Element substitution in Co-pentlandite and cobaltian mackinawite}

From the binary plots, it can be inferred that $\mathrm{Co} \rightarrow \mathrm{Fe}$ and $\mathrm{Co} \rightarrow \mathrm{Ni}$ substitution is dominant in Co-pentlandite. Also strong negative correlations between $\mathrm{Co}$ and $\mathrm{Fe}+\mathrm{Ni}$ and $\mathrm{Fe}$ and $\mathrm{Co}+\mathrm{Ni}$ imply that these elements substituted each other. Similar substitutions were observed earlier as well, especially in pentlandite from continental sources (Riley 1977), and is different from substitution scheme proposed by Borodaev et al. (2007) for mid-oceanic ridge hydrothermal system. In case of Khetri, the major substitution is $\mathrm{Co} \rightarrow(\mathrm{Ni}+\mathrm{Fe})$.

In case of mackinawite, thermodynamic study indicates that trace element bearing mackinawite is more stable relative to the pure phase (Kwon et al. 2015). Cobaltian mackinawite from the MadanKudan deposit is trace element-rich, in which $\mathrm{Ni}+\mathrm{Co}$ content is much higher than that of $\mathrm{Cu}$ (which is predicted by thermodynamic calculations of Kwon et al. 2015). The trace elements can take three places in the structure of mackinawite: (1) in place of Fe atom by substitution, (2) tetrahedral interstitial site and (3) square-pyramidal site. No significant correlation between $\mathrm{Fe}$ and $\mathrm{Co}$ or $\mathrm{Fe}$ and $\mathrm{Ni}$ likely indicate that some or all of the Co and $\mathrm{Ni}$ are present in the interstitial spaces. Strong correlation between $\mathrm{Co}$ and $\mathrm{Ni}$ indicate substitution of $\mathrm{Co}$ by $\mathrm{Ni}$ and vice versa, presumably at the same site. Similarly, weak negative correlation between $\mathrm{Cu}$ and $\mathrm{Co}$ and no discernible correlation of $\mathrm{Cu}$ with Fe likely indicates incorporation of $\mathrm{Cu}$ in the interstitial site too.

\subsection{Source of metal and Co enrichment relative to $\mathrm{Ni}$}

The host rocks, viz., amphibole-bearing albitic quartzite and garnetiferous chlorite schist are unlikely to contain high intrinsic concentrations of $\mathrm{Cu}, \mathrm{Fe}, \mathrm{Co}$ and $\mathrm{Ni}$. Therefore, the presence of sulphide veins comprising chalcopyrite, pyrrhotite, magnetite, Co-pentlandite, and cobaltian mackinawite in these host rocks indicate that $\mathrm{Cu}, \mathrm{Fe}$, $\mathrm{Co}$ and $\mathrm{Ni}$ were derived from extraneous source (see previous section). Mafic rocks contain higher concentrations of all these elements compared to common felsic igneous and metasedimentary rocks (Taylor et al. 1969), the latter constitutes a major part of the rock sequence in and around the deposits. Therefore, the possible source of these ore metals for this vein-hosted sulphide mineralization might be mafic rocks that are spatially associated (Sarkar and Dasgupta 1980a, b; Kaur and Meht 2005; Kaur et al. 2013) with these deposits. However, the ore minerals are significantly moreenriched in Co compared to $\mathrm{Ni}$, as is evident from the compositions of the minerals. Mafic rocks generally contain higher amount of $\mathrm{Ni}$ relative to Co $(\sim 120 \mathrm{ppm} \mathrm{Ni}$ vs. $\sim 50 \mathrm{ppm}$ Co; Taylor et al. 1969). Therefore, consistently high Co:Ni in the sulphide minerals need an explanation. Liu et al. (2012) demonstrated that Co is much more soluble than $\mathrm{Ni}$ in a Cl-rich hydrothermal solution. Therefore, transport of metals from a mafic source by Cl-rich solution, as inferred from mineralogy of sulphide veins and mineral chemistry (presence of Cl-rich amphibole \pm Cl-rich marialitic scapolite) suitably explains relative enrichment of Co compared to $\mathrm{Ni}$ in Co-pentlandite and cobaltian mackinawite. These metals were likely transported from the source to the depositional site as chloride complexes ( $c f$. Baidya et al. 2017). De-stabilization of Cl-complexes resulted in the crystallization of sulphide and Cl-rich amphibole and at places Clrich marialitic scapolite.

\subsection{Co-rich phases and probable deposit type}

Several models have been proposed regarding the origin of the $\mathrm{Cu}$-deposit of the Khetri copper belt. The proposed models include: (a) syn-sedimentarydiagenetic, prior to deformation and metamorphism, (b) peak- to post-peak-metamorphic hydrothermal, and (c) dual mode involving both the above (Roy Chowdhury and Das Gupta 1965; Das Gupta 1974; Sarkar and Dasgupta 1980a, b; Knight et al. 2002). In a latest study by Knight et al. (2002) it has been proposed that the mineralization in the Khetri deposit is hydrothermal and belongs to the Fe-oxide ( $\mathrm{Cu}-\mathrm{Au}$ ) (IOCG)-type of deposits.

Our study reveals that at least a part of the mineralization in the Madan-Kudan deposit is post-metamorphic and post-deformation hydrothermal in origin ( $c f$. Baidya et al. 2017). In addition to $\mathrm{Cu}$, the ores are enriched in $\mathrm{Co}$ and $\mathrm{Ni}$, particularly in $\mathrm{Co}$, as is indicated by the presence of Co-pentlandite and cobaltian mackinawite. In an independent study, Sen (2015) described the occurrence of $\mathrm{Co}-\mathrm{Ni}$ (mostly Co)-rich pyrite from the ores of Madan-Kudan deposit. Magnetite in association with these Co-rich phases are also enriched in Co relative to other type of magnetite present 
in this area (Chen et al. 2015). Cobalt-enriched ores of the deposits have also been reported by Knight et al. (2002). Iron oxide $\mathrm{Cu}-\mathrm{Au}$ deposits are generally characterized by high $\mathrm{Co} \pm \mathrm{Ni}$ abundance in general and in some of the deposits these elements occur in economic grade and quantity (Barton 2014). Cobalt-enrichment in IOCG deposits is mainly manifested in the high $\mathrm{Co}-\mathrm{Ni}$ concentration of pyrite and pyrrhotite (Mazdab 2001; Pal et al. 2009; Barton 2014), and in some deposits Co and $\mathrm{Ni}$ can form discrete sulphide, arsenide and arseno-sulphides (Slack 2012) similar to that of the Madan-Kudan deposit. The common mineralogical assemblage in which chalcopyrite (the abundant $\mathrm{Cu}$-mineral) occurs is represented by magnetite + pyrrhotite + chalcopyrite + Co-pentlandite + Co-rich mackinawite. Such a mineralogical assemblage is indicative of a relatively low $f \mathrm{~S}_{2}$ condition in which sulphides precipitated. It may be noted that IOCG deposits are invariably associated with a high salinity fluid, a similar situation as has been inferred for the sulphide veins in this study. Therefore $\mathrm{Cu}-\mathrm{Co}-\mathrm{Ni}$ mineralization via a Cl-rich fluid in a presumably low sulfidation environment collectively indicates that the deposit at MadanKudan has metal association and mineralogical and fluid characters akin to IOCG-style mineralization. However, more detailed study integrating types and patterns of hydrothermal alterations vis$\grave{a}$-vis mineralization, compositions of hydrothermal fluids, and thermo-tectonic evolution of the study area is warranted.

\section{Conclusions}

In the Madan-Kudan copper deposit, Khetri $\mathrm{Cu}$-belt, Rajasthan, epigenetic, hydrothermal copper mineralization is associated with sulphide veins comprising chalcopyrite-pyrrhotite \pm pyritemagnetite-chlorite-blue amphibole (Cl-rich hastingsite-pargasite-sadanagaite) \pm marialitic scapolite \pm allanite \pm uraninite. These veins occur in amphibole-bearing feldspathic/albitic quartzite and garnetiferous chlorite schist. Cobalt pentlandite and cobaltian mackinawite are the two important Co sinks, among which, to the best of our knowledge, cobalt pentlandite is being reported for the first time from the Khetri Cu-belt (perhaps from India as well). Although the immediate source of $\mathrm{Co}$ and $\mathrm{Ni}$ for Co-pentlandite and cobaltian mackinawite might have been pyrrhotite and chalcopyrite, the ore metals, viz., $\mathrm{Cu}, \mathrm{Fe}, \mathrm{Co}$ and $\mathrm{Ni}$ were brought in by the fluid ultimately from an external source, most likely the mafic rocks present in and around the study area. High saline Cl-rich nature of the fluid is inferred from the presence of Cl-rich amphibole and Cl-rich marialitic scapolite. Transport of Co and Ni (other metals as well), sourced from a mafic rock with high intrinsic $\mathrm{Ni} / \mathrm{Co}$ content, by such a high saline fluid suitably explains the dominance of Co over $\mathrm{Ni}$ in the ores. Metal association ( $\mathrm{Fe}, \mathrm{Cu}, \mathrm{Co}, \mathrm{Ni}, \mathrm{LREE}, \mathrm{U}$ ) as evident from the ore mineralogy of the veins, common presence of magnetite and rarity/absence of pyrite, inferred low $f \mathrm{~S}_{2}$ condition during mineral precipitation and high salinity of fluid collectively indicate that the post-metamorphic, post-deformation mineralization has many character akin to IOCG-type deposits of the world.

\section{Acknowledgements}

The analytical expenditure was supported by the Department of Science and Technology, Government of India (DST-GOI)-funded 'Promotion of University Research and Scientific Excellence (PURSE)' - phase-I program of Jadavpur University (No. SR/S9/Z-23/2008/5). ASB acknowledges the financial grant received from Council for Scientific and Industrial Research (CSIR) through Shyama Prasad Mukherjee fellowship (Reference No. SPM-09/096(0184)/2013-EMR-I). Mr. A Ghosh, Director, Mining and Mr. A K Sen, Executive Director (mining) of Hindustan Copper Limited is thanked for giving permission to work in the mine and providing all logistic supports. Mr. A K Singh, Mr. B Kanjilal, Mr. N Sahoo and Dr. Rathi and other officials of Hindustan Copper Ltd. extended all necessary support and helped during the field work in and around Kolihan-Chandmari. We thank Mr. Saptarshi Sinha for his help during EPMA analysis at the Department of Geology and Geophysics, IIT, Kharagpur. Constructive suggestions and criticism from two anonymous reviewers helped to improve the manuscript significantly and are gratefully acknowledged. We also extend our sincere thanks to the associate editor, Prof. Rajesh Kumar Srivastava for carefully handling the manuscript and for his timely responses.

\section{References}

Baidya A S, Paul J, Pal D C and Upadhyay D 2017 Mode of occurrences and geochemistry of amphibole in the Kolihan-Chandmari copper deposits, Rajasthan, India: Insight into the ore-forming process; Ore Geol. Rev. 80 1092-1110. 
Barton M D 2014 Iron oxide (-Cu-Au-REE-P-Ag-U-Co) systems; In: Treatise on Geochemistry, 2nd edn, Elsevier Inc. 13 515-541.

Bayliss P 1977 Crystal structure refinement of a weakly anisotropic pyrite; Am. Mineral. 62 1168-1172.

Borodaev Y S, Bryzgalov I A, Mozgova N N and Uspenskaya T Y 2007 Pentlandite and Co-enriched pentlandite as characteristic minerals of modern hydrothermal sulphide mounds hosted by serpentinized ultramafic rocks (Mid-Atlantic Ridge); Moscow Univ. Geol. Bull. 62(2) 85-97.

Chen W T, Zhou M F, Li X, Gao J F and Hou K 2015 In-situ LA-ICP-MS trace elemental analyses of magnetite: $\mathrm{Cu}-$ $(\mathrm{Au}, \mathrm{Fe})$ deposits in the Khetri copper belt in Rajasthan Province, NW India; Ore Geol. Rev. 65 929-939.

Choudhary A K, Gopalan K and Sastry C A 1984 Present status of the geochronology of the Precambrian rocks of Rajasthan; Tectonophys. 105 131-140.

Clark A H 1970 Nickelian mackinawite from Vlakfontein, Transvaal: A discussion; Am. Mineral. 551802 1807.

Craig J R, Vaughan D J and Hagni R D 1981 Ore microscopy and ore petrography; 2nd edn, Wiley, New York.

Das Gupta S P 1968 The structural history of the Khetri copper belt, Jhunjhunu and Sikar districts, Rajasthan; Geol. Surv. India Memoir 98 1-170.

Das Gupta S P 1974 Geological setting and origin of sulphide deposits in the Khetri copper belt, Rajasthan; J. Geol. Min. Metall. Soc. India 46 223-238.

Deb S and Mukherjee A D 1969 Mackinawite from MadanKudan and Kolihan sections of Khetri copper belt, Rajasthan; Proc. Indian Nat. Sci. Acad. 35 533-541.

Francisi C A, Stz M E F and Mlsna Q 1976 Orientation of exsolved pentlandite in natural and synthetic nickeliferous pyrrhotite; Am. Mineral. 61 913-920.

Geller S 1962 Refinement of the crystal structure of $\mathrm{Co}_{9} \mathrm{~S}_{8}$; Acta. Crystallogr. 15(12) 1195-1198.

Gibbons G S 1967 Optical anisotropy in pyrite; Am. Mineral. 52(3-4) 359-370.

Gopalan K, Macdougall J D, Roy A B and Murali A V 1990 Sm-Nd evidence for 3.3 Ga old rocks in Rajasthan, northwestern India; Precamb. Res. 48 287-297.

Gupta P, Guha D B and Chattopadhyay B 1998 Basementcover relationship in the Khetri copper belt and the emplacement mechanism of the granite massifs, Rajasthan, India; J. Geol. Soc. India 52 417-432.

Harris D C and Nickel E H 1972 Pentlandite compositions and associations in some mineral deposits; Can. Mineral. 11 861-878.

Heron A M 1953 The geology of central Rajputana; Geol. Surv. India Memoir 79 389p.

Jaireth S 1984 Ore paragenesis and fluid-inclusion thermometry of copper sulphide ores from Madan-Kudan and Kolihan deposits; Geol. Surv. India Spec. Publ. 12 551568.

Jaireth S 1986 Igneous source of Sulfur of Sulphides from Madhan-Kudhan and Kolihan Deposits, Khetri Copper Belt, Rajasthan; J. Geol. Soc. India 27 359-368.

Kaur G and Meht P K 2005 The Gothara plagiogranite: Evidence for oceanic magmatism in a non-ophiolitic association, North Khetri Copper Belt, Rajasthan, India; J. Asian Earth Sci. 25(5) 805-819.
Kaur P, Chaudhri N, Biju-Sekhar S and Yokoyama K 2006 Electron probe micro analyzer chemical zircon ages of the Khetri granitoids, Rajasthan, India: Records of widespread late Palaeoproterozoic extension-related magmatism; Curr. Sci. 90 65-73.

Kaur P, Chaudhri N, Raczek I, Kröner A and Hofmann A W 2007 Geochemistry, zircon ages and whole-rock Nd isotopic systematics for Palaeoproterozoic A-type granitoids in the northern part of the Delhi belt, Rajasthan, NW India: Implications for late Palaeoproterozoic crustal evolution of the Aravalli craton; Geol. Mag. 144 361-378.

Kaur P, Chaudhri N, Raczek I, Kröner A and Hofmann A W 2009 Record of $1.82 \mathrm{Ga}$ Andean-type continental arc magmatism in NE Rajasthan, India: Insights from zircon and $\mathrm{Sm}-\mathrm{Nd}$ ages, combined with $\mathrm{Nd}-\mathrm{Sr}$ isotope geochemistry; Gondwana Res. 16 56-71.

Kaur P, Chaudhri N, Raczek I, Kröner A, Hofmann A W and Okrusch M 2011 Zircon ages of Late Palaeoproterozoic (ca. 1.72-1.70 Ga) extension-related granitoids in NE Rajasthan, India: Regional and tectonic significance; Gondwana Res. 19 1040-1053.

Kaur P, Chaudhri N, Hofmann A W, Raczek I, Okrusch M, Skora S and Baumgartner L P 2012 Two-stage, extreme albitization of A-type granites from Rajasthan, NW India; J. Petrol. 53 919-948.

Kaur P, Chaudhri N, Hofmann A W, Raczek I and Okrusch M 2013 Geochemistry and Sm-Nd geochronology of the metasomatised mafic rocks in the Khetri complex, Rajasthan, NW India: Evidence of an Early Cryogenian metasomatic event in the northern Aravalli orogen; $J$. Asian Earth Sci. 62 401-413.

Kaur P, Chaudhri N, Hofmann A W, Raczek I, Okrusch M, Skora S and Koepke J 2014 Metasomatism of ferroan granites in the northern Aravalli orogen, NW India: Geochemical and isotopic constraints, and its metallogenic significance; Int. J. Earth Sci. 103 1083-1112.

Kerestedjian T N and Bonev I K 2001 Complex argentopentlandite-mackinawite inclusions in chalcopyrite: A solid state exsolution mechanism; Geochem. Mineral. Petrol. 38 23-33.

Knight J, Lowe J, Joy S, Cameron J, Merrillees J, Nag Shah N, Dua G and Jhala K 2002 The Khetri copper belt, Rajasthan: Iron oxide copper-gold terrane in the Proterozoic of NW India; In: Hydrothermal iron oxide copper-gold and related deposits: A global perspective (ed.) Porter T M, PGC Publishing, Adelaide, pp. 321-341.

Kuovo O, Huhma M and Vuorelainen Y A 1959 Natural Cobalt Analogue of Pentlandite; Am. Mineral. 44 897-900.

Kwon K D, Refson K and Sposito G 2015 Transition metal incorporation into mackinawite (tetragonal $\mathrm{FeS}$ ); $\mathrm{Am}$. Mineral. 100(7) 1509-1517.

Lal R K and Ackermand D 1981 Phase petrology and polyphase andalusite-sillimanite type regional metamorphism in pelitic schists of the area around Akhwali, Khetri Copper Belt, Rajasthan, India; Neues Jb. Miner. Abh. 141 161-185.

Lal R K and Shukla R S 1975 Low pressure regional metamorphism in the northern portion of the Khetri Copper Belt of Rajathan, India; Neues Jb. Miner. Abh. 124 294-325. 
Liu W, Migdisov A and Williams-Jones A 2012 The stability of aqueous nickel (II) chloride complexes in hydrothermal solutions: Results of UV-visible spectroscopic experiments; Geochim. Cosmochim. Acta 94 276-290.

Mallet F R 1881 On cobaltire and danaite from the Khetri mines, Rajputana, with some remarks on Jaipurite (Seyporite); Rec. Geol. Surv. India 14 190-196.

Mariko T 1988 Ores and ore minerals from the volcanogenic massive sulphide deposits of the Shimokawa mine, Hokkaido, Japan; Mining Geol. 38(209) 233-246.

Mazdab F K 2001 The distribution of trace elements in iron sulphides and associated Cl-bearing silicate minerals; Unpublished PhD thesis, University of Arizona, Arizona, USA.

Merkle R K and von Gruenewaldt G 1986 Compositional variation of Co-rich pentlandite: Relation to the evolution of the upper zone of the western Bushveld Complex, South Africa; Can. Mineral. 24(3) 529-546.

Middleton J 1846 LVI. Analysis of cobalt ore found in western India; Philos. Mag. J. Sci. London, Edinburgh Dublin 28(188) 352-354.

Mukherjee A D 1976 Compositional variation of naturally occurring mackinawite; Neues Jb. Miner. Abh. 2 69-79.

Mukherjee A D and Sen P P 1991 Compositional variations in mackinawites from the Chandmari mine of khetri copper belt, Rajasthan; J. Geol. Soc. India 38(1) 96-100.

Murowchick J B 1992 Marcasite inversion and the petrographic determination of pyrite ancestry; Econ. Geol. 87(4) 1141-1152.

Naha K, Mukhopadhyay D K and Mohanty R 1988 Structural evolution of the rocks of the Delhi Group around Khetri, northeastern Rajasthan; In: Precambrian of the Aravalli Mountain, Rajasthan, India (ed.) Roy A B, J. Geol. Soc. India 7 207-245.

Nicol J 1849 Manual of mineralogy; Edinburgh; Adam and Charles Black, 576p.

Pal D C, Barton M D and Sarangi A K 2009 Deciphering a multistage history affecting $\mathrm{U}-\mathrm{Cu}(-\mathrm{Fe})$ mineralization in the Singhbhum Shear Zone, eastern India, using pyrite textures and compositions in the Turamdih $\mathrm{U}-\mathrm{Cu}(-\mathrm{Fe})$ deposit; Miner. Deposita 44 61-80.

Pant N C, Kundu A and Joshi S 2008 Age of metamorphism of Delhi Supergroup rocks-electron microprobe ages from Mahendragarh district, Haryana; J. Geol. Soc. India 72 365-372.

Ramdohr P 1980 Ore minerals and their intergrowths; Pergamon Press Ltd., England.

Rao N K and Rao G V U 1968 Ore microscopic study of copper ore from Kolihan, Rajasthan, India; Econ. Geol. 63(3) $277-287$.

Riley J F 1977 The pentlandite group (Fe,Ni,Co) $9 \mathrm{~S}_{8}$ : New data and an appraisal of structure-composition relationships; Mineral. Mag. 41 345-349.

Ross W A 1872 On Jeypoorite, a Sulph-Antimonial Arsenide of Cobalt; Proc. Royal Soc. London 21(139-147) 292-297.

Roy A B 1988 Stratigraphic and tectonic framework of the Aravalli Mountain Range; Geol. Soc. India Memoir 7 $3-31$.
Roy A B and Jakhar S R 2002 Geology of RajasthanPrecambrian to Recent; Scientific Publication (India), Jodhpur, 421p.

Roy A B and Kröner A 1996 Single zircon evaporation ages constraining the growth of the Archaean Aravalli craton, northwestern Indian Shield; Geol. Mag. 133 333-342.

Roy Chowdhury M K and Das Gupta S P 1965 Orelocalization in the Khetri copper belt, Rajasthan, India; Econ. Geol. 60 69-88.

Sahu K C, Panchapakesan V and Patil R R 1977 Fluid inclusion studies on samples from Kolihan Mines of Khetri Copper Belt; J. Geol. Soc. India 18(12) 671674.

Sarkar S C 1971 Mackinawite from sulphide ores of Singhbhum copper belt, India; Am. Mineral. 56(7-8) 1312.

Sarkar S C and Dasgupta S 1980a Geologic setting, genesis and transformation of sulphide deposits in the northern part of Khetri copper belt, Rajasthan, India - an outline; Mineral. Deposita 15 117-137.

Sarkar S C and Dasgupta S 1980b A study of pre-existent ores at the intrusive-contact and the origin of the late hydrothermal veins at the Madan Kudan and Kolihan Mines, Khetri Copper Belt, Rajasthan, India; Neues Jb. Miner. Abh. 139 102-112.

Sarkar S C and Gupta A 2012 Crustal evolution and metallogeny in India: Delhi; Cambridge University Press, 840p.

Sen A 2015 Texture and geochemistry of sulphides and carbon and oxygen stable isotope studies of carbonates from Khetri copper deposit, Rajasthan, India: Implications for hydrothermal sulphide mineralization; M.Sc Thesis, Jadavpur University, Kolkata, India, 59p.

Sinha-Roy S 1984 Precambrian crustal interaction in Rajasthan, NW India; Indian J. Earth Sci. CEISM Seminar volume, pp. 84-91.

Slack J F 2012 Strata-bound $\mathrm{Fe}-\mathrm{Co}-\mathrm{Cu}-\mathrm{Au}-\mathrm{Bi}-\mathrm{Y}-\mathrm{REE}$ Deposits of the Idaho Cobalt Belt: Multistage hydrothermal mineralization in a magmatic-related iron oxide copper-gold system; Econ. Geol. 107(6) 1089-1113

Stanton R L 1959 Studies of polished surfaces of pyrite and some implications; Can. Mineral. 6 87-118.

Tatsumi T, Nakayama F, Urabe T and Shimazaki H 1975 Carrollite from the Sazare mine, Ehime Prefecture, Japan; Mineral. J. 7(6) 552-561.

Taylor S R, Kaye M, White A J R, Duncan A R and Ewart A 1969 Genetic significance of Co, Cr, Ni, Sc and V content of andesites; Geochim. Cosmochim. Acta 33(2) 275-286.

Tobisch P O T, Collerson K D, Bhattacharyya $\mathrm{T}$ and Mukhopadhyay D 1994 Structural relationships and Sr$\mathrm{Nd}$ isotope systematics of polymetamorphic granitic gneisses and granitic rocks from central Rajasthan, India: Implications for the evolution of the Aravalli craton; Precamb. Res. 65 319-339.

Vaughan D J 1969 Nickelian mackinawite from Vlakfontein, Transvaal; Am. Mineral. 54(7-8) 1190.

Wiedenbeck M, Goswami J N and Roy A B 1996 Stabilization of the Aravalli craton of northwestern India at 2.5 Ga: an ion microprobe zircon study; Chem. Geol. 129 325-340. 